\title{
Nature manifestation in philosophy, diagnosis and treatment of disease based on Ayurvedic and Malay traditional medicine: A comparative study
}

\author{
Wan Faizah Wan Yusoff ${ }^{1 *}$ \\ ${ }^{1}$ Pusat Pengajian Sains Kesihatan, Universiti Sains Malaysia, Kubang Kerian Kelantan
}

\begin{abstract}
Man and nature is an important concept in the traditional community's universal perspective. This concept can be seen in the universal and cosmological view which discusses questions on the origin of human and nature existence. In traditional medicine context such as Ayurvedic and Malay, this nature manifestation not only can be seen in medical philosophy but also diagnosed medically, as well as treatment given to the disease. This research paper discussion is focused on the community's conception towards natural elements either physically or the opposite and the manifestation of understanding towards their medical philosophy. Among the concept that will be discussed are natural elements such as soil, water, fire, air and ether or better known as the space which is not only important in the context of nature composition but also in the human body based on Ayurvedic medicine. Research is done through the observation of literature and interview with Ayurvedic and Malay traditional medicine practitioners. The outcome obtained has shown that there is a difference between the diagnosis and Ayurvedic treatment which focuses on the characteristics and physical signs compared to traditional Malay medicine which also includes personality diagnostic methods as well as physical attributes and signs for the purpose of disease diagnosis.
\end{abstract}

Keywords: traditional Malay medicine, Ayurvedic medicine, cosmology, diagnosis, treatment

\section{Introduction}

The traditional medicine system is a cultural heritage which reflects the thinking of the community for years which is in relations to disease etiology, prevention and treatment method. This medical thought is mostly shaped by the universal view of the community which is also influenced by religion in light of the change of the era just like traditional Malay medicine. In the context of the Malay community, the traditional worldview which also originates from animism and dynamism has faced adjustments with the influence of Hindu-Buddhist and Islam. The worldview of the Indian community is also influenced by

\section{*Corresponding author: faienur@usm.my}

elements originating from their faith. Four main life objectives related to Ayurvedic traditional philosophy are dharma (religious tasks implementation), artha (wealth accumulation), kama (fulfillment of desires) and moksa (liberation from worldly ties). In this context, optimal health is considered as a prerequisite or sire qua non for the attainment of the four objectives.

In Malay and Indian traditional medicine, the relationship between patient, healer and natural elements is truly important and inter-related with each other. This humoral concept and elements and its understanding indirectly shows uniqueness between one traditional system with other traditional medicine system. This research paper will focus on 
nature's concept in the form of microcosmos and macrocosmos related with traditional Malay and Ayurvedic medicine to show different elements that serves as uniqueness to each of the medication system. Discussion will also cover the diagnosis method and disease classification as treatment methods based on both medication systems.

\section{The Concept of Microcosmos and Macrocosmos in Traditional Malay and Ayurvedic Medicine}

Nature, according to Malay understanding is divided into two which is microcosmos which is the human as a small nature covering the physical, mind, soul, spiritual, and others as well as macrocosmos which covers the environment and supernatural [6]. In the context of the essence of existence, human is macrocosmos whereas nature is microcosmos since human is placed closer to God. The nature dissident existence in the human body does not refer to the presence of the dissidents physically but only as a symbol which describes the natural manifestation in the human body. In this context, human is the symbol of nature existence as seen from the seven important organs such as the brain, bone, muscle, blood, skin, vein and large vein which describes the seven heavens [8].

Four main elements of the human body based on Malay understanding are blood, balgham or mucus, yellow bile water and black bile water which are a symbolic of the four natures. These elements are important in producing temperament which is the disposition and temperament which is unique for each individual as observed in the natural phenomena which arise due to the combination of the four elements. Each element must be balanced in order to avoid imbalance which can next contribute to a disease [8]. The microcosmos and macrocosmos concept is also seen in traditional Indian medicine such as Ayurveda.

According to the teaching of Ayurveda, the humans are a microcosmos which is the universe and himself. The whole universe including the human are made up of five elements which is space, water, fire, wind and soil which does not only form the universe (macrocosmos) and human body (microcosmos). Based on the understanding, the effects of cosmic vibration in the universe are believed to be producing ether or space. The movement of ether produces the air which instigates friction and next, heat. The heat particles produced combines with light to create fire. The heat produced will melt ether elements producing water whereas water that solidifies produces soil or earth molecules. The five elements not only form the universal composition but also shape all other events. Water for instance is in the form of ice which has hard element such as soil. Fire element in ice also melts and produces water. With the help of heat, water produces vapour which has the element of air [11].

Since human is the microcosmos of the universe, based on the views of Ayurvedic medicine, the five elements which shapes the universal composition also dominates the individual self. The element of space or ether covers the space available in the oral cavity, nose, stomach, and blood capillary whereas air refers to body metabolism which works in the digestion system and also brain function which refers to intellect. The element of fire is also believed to activate the retina to enable us to see light. Water is on the other hand manifested in the form of digestive juice, mucous, blood plasma and etc which is an important element in the body. The soil element refers to the structure of the human body which is solid including bones, muscles and tendon [11]. Similar understanding could be seen in the context of Malay traditional medicine.

Based on Malay cosmology, all beings, natural phenomenon as well as food or medicine are formed from the basic element which is soil, water, fire and wind. However, there is one dominant element for each being with two different habits. The earth element for example has two different habits which is wet and cold. Its single attribute only describes God whereas the created beings have two attributes which are coupled and function simultaneously [7]. This combined concept is also available in the Ayurvedic philosophy. Tridosha or three basic energy principles or functions that exist in inside human which comprises of vata, pitta, and kapha is the combination of the five elements. From the spiritual viewpoint, tridosha refers to the defects, deficiencies, sins and mistakes in response action, response, processing, integration and disintegration of human with the material world. Therefore, the excessive existence of tridosha which comprises of vata, pitta, and kapha could give negative effects such as disease to humans [9, 11].

Health in the context of Ayurveda and traditional Malay medicine also has a direct relationship with natural elements. The influence and changes of nature such as seasons and cold or hot weather has a direct effect on the human health. Malay Kitab Tibb such Tajul Muluk and Bintang Dua Belas also relates disease and health with the celestial 
movements [7]. Therefore, the suitable time to undergo treatment is when patient and universe are in harmony. The medication prescribed to patient also has symbols representing certain universe elements in order to create a harmonious relationship between human and nature. This view is also shared by the Indian community which places celestial movement and certain time such as lunar moment and midday as two of the important elements related to bad luck which can also affect treatment. The appearance of certain signs from nature resources such as the sound of owls, the appearance of snakes or the blowing of cold and slow wind which is also believed to be related to bad luck which should be avoided in the process of treatment [9].

\section{Diagnosis Method and Disease Classification Based on Traditional Malay and Ayurvedic Medicine}

Classification and disease treatment are determined based on the source of the disease. There are two methods in classifying a disease or nosology based on Kitab Tibb, Bustan al-Salatin and Taiyib al-Ihsan. The first method is referring to the diseases related to body parts involved such as the head, sensory organs, abdomen, the lower body part or the skin. These diseases are also divided into certain types based on the symptoms showed for example typhoid which are categorized into fire typhoid, heat typhoid and trembling typhoid. The second method is by classifying the disease whether it is cold because of excessive balgham or mucus; heat because of excessive blood humour or related to humour such as yellow fever due to excessive water in the body [7].

Apart from the humour determination method in the body which can instigate sickness, Malay medicine also outlines other methods in identifying the stability or humour changes in the body. This method is based on the examination of pulse movement. Compared to pulse examination in Malay medicine which focuses on the thick, thin as well fast or slow movement of the pulse itself [7], the method used to read the movement of the pulse in Ayurveda is by comparing the movement to movement pattern of animals to show dosha which dominates the patient body as shown in the table below [9]:

\begin{tabular}{|l|l|}
\hline Movement pattern & Dominating dosha \\
\hline Snake or leech & vata \\
\hline Crow, sparrow, frog & pitta \\
\hline Swan, peacock or cockerel & kapha \\
\hline Monkey, swan & pitta and kapha \\
\hline Woodpecker or carpenter & vatta, pitta and kapha \\
\hline
\end{tabular}

Apart from the physical-related diagnosis, Malay medicine also shows emphasis on personality methods which involves rituals such as trance, prophecy, and the likes of it using methods or source of specific intermediaries to identify the causes of disease. The knowledge in prophecy especially in astrology has been the culture of the Malays [10]. Kitab Tibb and MSS 3290 for example predict the disease which one will contract based on their birth month. Individuals born in the Islamic month of Rabiul Akhir for example are said to be epileptic and are physically hot whereas individuals born in Jamadil Awal have the tendency to have wind-related disease. The use of intermediary sources such as the Malay weapon, kris that popularized the term 'keris berdiri' or the standing kris clearly shows the beliefs of the community on mystical sources which also help identify future diseases [5]. Aside from kris, other intermediary sources commonly used are kernels which are counted in pairs based on nature element such as soil, water, fire and wind which form the human body. Based on the number of kernels in each part, the shaman will interpret the meaning of elements and next identify the disease [2]. This method shows clear differences in traditional Malay and Ayurvedic medicine.

\section{Treatment Method Based On Traditional Malay and Ayurveda Medicine}

The concept of Malay medicine regarding medication covers the pharmaceutical material used in treatment and prevention of disease and as a remedy for poison or toxic-based diseases. The intake of certain food or medicine in the context of Malay medicine is for the purpose of changing or influencing humor in the body and not directed to specific organs just like in modern medicine [7]. The medical material used in modern Malay medicine covers quite a number of different types of herbs and roots from nature as specifically stated for the parts needed to be used. These 
plants were given specific names and most of it could be standardized with the names used today such as white pepper, turmeric, garlic, jeтиju, white cumin, black cumin, cumin, turmeric, galangal, cloves and others [4]. In light of the humoural doctrin, the medical material in Malay medicine based on Bustan al-Salatin and an observation on local practices can be classified into its criteria and health benefits. The medical material such as sour, bitter, stew, slimy, chewy, and watery are categorized as cold and used to treat diseases that are hot in nature [8]. The treatment method is humoral based on alopathy principal or contrana contranis by giving food or medication opposite of the disease complications. Diseases categorized as cold such as epilepsy will be treated using heat-based medication such as turmeric, sesame oil and the likes of it to prevent the disease from cold infiltration [7].

Based on the observation of the Kitab Tibb Pontianak, the floral choice was made with full accuracy and not only limited to the use of leaves to expose each plant's benefits which also includes fruits, seeds, skin and roots in which each of it has its own therapeutic values [1]. In order to ensure the effectiveness of treatment, medicinal plants are harvested at specific time by giving focus on seasonal changes since plants' active ingredients do not only change according to the condition of the soil and climate but also change according to season. In fact, age and maturity of the plants are also taken into consideration in order to ensure the quality and value of the active ingredients [3]. Apart from botanical, other materials also used in traditional medicine are animals, such as their internal organs, skin, horns and others including minerals such as salt, bauxite, sulphur and other valuable minerals such as gold and silver $[1,4]$.

Based on Ayurvedic medicinal practice, the main aspects which should be focused on in determining medical materials suitable for diseases are by identifying the causes of diseases, early signs and symptoms based on the law of causes and effects. The selection of medical material in principle is based on the opposite attributes of the disease causes or the disease itself. As for example, the use of kuinin is believed to be the best medication for malaria. Similar method was accepted for use in homeopathy medicine. The single or combined use of medicine also shows similarity with traditional Malay medicine as discussed earlier on in modern medicine [9].

The source of Ayurvedic medical material comprises of plants, animals and minerals such as that in Malay medicine. According to Ayurveda, medicinal plants can be divided into two types which is cold or hot in nature based on the taste which was also discussed in Malay medicine. Medicinal plants which are categorized as hot in principle has a strong, sour and salty taste whereas cold medicinal plants has a sweet and bitter taste. Each taste, according to Ayurveda has its own benefits in treatment of disease. The sweet (madhura rasa) for example is good for the health of the brain, heart, throat and skin apart from being able to treat burns and quench thirst. The sweet taste can also increase milk production, body growth and skin condition. However, if taken excessively, it will give a negative effect such as the formation of fat, increase of weight and causes laziness as well as the loss of appetite, weaken the digestion and causing diseases such as coughing, fever as well as cold [9].

Apart from the changes in food intake and balancing excessive dosha in order to avoid a disease, Ayurveda also emphasized on food adjustments according to seasonal suitability to avoid seasonal change disease or the 'Three Season Diet'. Based on the observation made in winter for example, animals such as squirrels take a lot of protein such as beans. Therefore, the intake of the same protein is also encouraged in Ayurveda in order to maintain health in winter. During fall, one is encouraged to take green plants and seasonal fruits such as berries to avoid allergic-based disease and the accumulation of mucus which happens a lot during that season [9].

The influence of seasons and specific time are also emphasized in Malay medicine. According to the MS33 Kitab $T i b b$, the wind humor is dominant in summer whereas blood humor is active in moderate season. Wet or monsoon season shows that balgham or mucus is more dominant. Apart from that, there are also certain times in a day when some humour loses its balance and may cause diseases. Morning time especially shows a tendency to bring the wind humour disease whereas the evening is related to the balgham or mucus humour-based disease. In the night time, there is also a tendency for diseases caused by the imbalanced of wind and balgham or mucus. The day shows diseases caused by the imbalanced of blood and wind humour. Therefore, in facing certain seasons, the intake of suitable diet is encouraged in order to ensure optimal health [7].

\section{CONCLUSION}

Malay medicine shows knowledge and local wisdom based on the accumulation of knowledge and experience as well as interaction with different culture. Research on the essence of Malay medicine manuscript or Kitab Tibb is important because it includes different viewpoints compared to what has always been composed by the orientalists aside from 
showing the scientific sides of Malay medicine. Although there are differences between the diagnosis and treatment in traditional Malay and Ayurvedic medicine, in principle, there are similarities in certain health concepts such as the context of human relationship self with the nature which shows a mutualism symbiosis that cannot be separated. The manifestation of nature in Malay and Ayurvedic medicine is clearly shown not only in diagnosis but also in its holistic and unique nature of treatment compared to modern medication which only focuses on certain aspects, separating individuals not only from himself as a whole but also from his relationship with the community and nature. The knowledge of Malay and Ayurvedic medicine which has been used and tested on its effectiveness for decades has seen a focus on the inter-related relationship between human and nature as well as adjustments to the environment in order to create harmony and balance. The relationship between physical, spiritual, environmental, psychology and health in Malay and Ayurvedic medicine shows that knowledge and local wisdom are not only high in value but also a source of amazement.

\section{References}

1. Abdul Razak Abdul Karim, Analisis Bahasa dalam Kitab Tib Pontianak (Dewan Bahasa dan Pustaka, Kuala Lumpur, 2006)

2. Aishah Mohamed dan Aziz A. Bidin, GMJSS, 8, 4 (2012).

3. Faisal @ Ahmad Faisal Abdul Hamid dan Nurul Wahidah binti Fauzi, Jurnal al-Tamaddun, 7 (2012)

4. Harun Mat Piah, IMAN, 3, 3 (2015).

5. Mohd Farhan Md. Ariffin, Khadher Ahmad, Nor Izati Samsudin, Mohamad Zaim Ismail \& Muhammad Ikhlas Rosele, GJAT, 3, 2 (2013).

6. Muhammad 'Uthman El-Muhammady in Yaacob Haron (Ed), Pemikiran Melayu dalam Kosmologi Melayu, p. 10-22 (APMUM, Kuala Lumpur, 2001)

7. Pisol Maidin, Konsep Kesihatan dan Etnofarmakologi: Satu Kajian Falsafah Berdasarkan Beberapa Naskhah Manuskrip Perubatan Tradisional Bustan al-Salatin, Kitab Tibb dan Taiyyib al-Ihsan (Unpublished dissertation, Universiti Malaya, 1995)

8. Pisol Maidin in Rahimah A.Hamid, Mohd Kipli Abdul Rahman \& Nazarudin Zainun (Ed), Kearifan Tempatan: Pengalaman Nusantara Meneliti Khazanah Sastera, Bahasa dan Ilmu, p. 180-192 (Penerbit USM, Penang, 2013).

9. Sharma, S.C, Ayurveda the ultimate medicine (Wisdom Tree, New Delhi, 2005).

10. Syed Haashim Syed Abdul Rahman Kosmologi Kitab Tibb Melayu: Satu Penghayatan Awal, Proceeding of Seminar Sains dan Teknologi Malaynesia (2017).

11. Vasant, L. Ayurveda the science of self-healing: A practical guide (Lotus Press, Wisconsin, 1990). 